\title{
Studying the Effect of the Different Position Piers on the Scour in the Curved Channels
}

\author{
Mamdouh Ahmed Dardeer ${ }^{1}-$ Ahmed Helmy $^{2}$ \\ Lecturer, Civil Engineering Department, Al-Azhar University, Egypt.
}

\begin{abstract}
The scour around the piers of bridges greatly affects the safety and balance of the bridges, and many studies have been done in which the scour around the piers in straight channels has been studied. It has been proposed and used of 3 piers of different shape (3 models) (elliptical $\left(M_{1}\right)$, Hexagonal $\left(M_{2}\right)$ and Oblong $\left(M_{3}\right)$ ). The effect of the different position of the pile on the curved canals, as well as the effect of the shape of the pile and the shape of the foreground on the depth and length of the erosion around the pier has been studied. Twenty-four laboratory experiments were conducted under different conditions of discharge. The experiment has been carried out in a glass-walled rectangular flume with a length of 8.00 meters (i.e., $30 \mathrm{~cm} \times 60 \mathrm{~cm}$ ). It is divided into three sections (the first and last sections are 3.0 $m$ in length, $60 \mathrm{~cm}$ in width, and $30 \mathrm{~cm}$ high, respectively; the third section, in the middle, is curved with a horizontal angle of $30^{\circ}$ and is $2.0 \mathrm{~m}$ in length). The experimental program has been developed to investigate relative $(b / B=0.5)$ under five different discharge conditions (14.70, 20.32, 24.47, 27.30, and $31.86 \mathrm{l} / \mathrm{sec})$. The water levels and depths, and the scour length and depth, were all measured using ultrasonic device. The models of the piers were placed at three positions of the curved part (Curved angle) the front of curved $\left(\theta=0.0^{\circ}\right)$, middle of curved $\left(\theta=15^{\circ}\right)$ and end of curved $\left(\theta=30^{\circ}\right)$, and it was found that the depth and length of the scour on the shape of the pile and also according to the different position of the place of the pile on the curved part, where the results were given The lowest percentage of scour depth occurred in the middle of curved $\left(\theta=15^{\circ}\right)$ of the Hexagonal shape $\left(M_{2}\right)$. The highest percentage of scour depth occurred in the first of curved $\left(\theta=0.0^{\circ}\right)$ of the oblong shape $\left(M_{3}\right)$. The lowest percentage of scour length occurred in the end of curved $\left(\theta=30^{\circ}\right)$ of the Elliptical shape $\left(M_{1}\right)$. The highest percentage of scour length occurred in the first of curved $\left(\theta=0.0^{\circ}\right)$ of the Hexagonal shape $\left(M_{2}\right)$.
\end{abstract}

Keywords: Scour, Piers, Curved Channels

\section{Introduction:}

The cost of constructing a bridge pier in an erodible riverbed is high because the foundation must be dug deep enough to provide the required anchorage length for the foundation's safety. As a result, bridge failure owing to scour results in financial loss and might result in human life loss. Local scour at piers is determined by the bed materials, bed configuration, flow parameters, fluid characteristics, and pier and footing geometry, Local scour at piers has been widely researched in the lab, but there is little field data. The laboratory investigation of complicated piers. Model studies of real or proposed pier designs are frequently used in the study of complicated piers. Many pier scour equations have been developed as a consequence of laboratory research.

Many researchers investigated scour around bridge piers and abutments, among them, for example are:-

Khodabakhshi, et al., (2014) stated that many bridges in the world every year, for not considering the hydraulic elements in the design, are destroyed. In the 1987 spring floods, scour destroyed or damaged 17 bridges in New York and New England. Floods in Pennsylvania, Virginia, and West

* Corresponding author.

E-mail address: Ahmedbadr3000@hotmail.com (A.helmy) Tel:+2-01111633022 
Virginia in 1985 destroyed 73 bridges. They investigated the impact of a slot (height "D" and width "D/4") on a circular pier, where "D" is the diameter of the bridge pier, under three different discharges $(35,40$, and 45 liters $/ \mathrm{sec})$ and four distinct slot locations in a flume (i.e., length of $14 \mathrm{~m}$, height of 60 , and width of $60 \mathrm{~cm}$ ). The experimental findings indicated that when the slot's height is under the stream bed, the scour depth in front of the pier is decreased by 20.34-39.73\%, and the scour volume is reduced by $46.84-75.74 \%$. Mubeen Beg, Salman Beg (2013), stated that scour around bridge piers must be controlled for safe and cost-effective design. The effectiveness of any scour protection/controlling system installed around bridge piers is determined by how well it counteracts the process of scouring. He further reported that efforts have been made to decrease scour depth by putting riprap around the pier, supplying an array of piles at the front of the pier, a collar around the pier, submerged vanes, a delta-wing-like fin at the front of the pier, a slot through the pier, and partial pier-groups in which tetrahedron frames have been put around the pier. They carried out a thorough analysis of current work on scour minimization at bridge piers, taking into account all relevant factors like flow field, scouring process, scour depth-affecting parameters, and scour time variation.

Mubeen Beg (2013) mentioned that calculating the maximum local scour depth at bridge piers correctly is critical for safe and cost-effective bridge design. For a similar data set, the available predictors yield a broad range of scour estimates. He testified that he compared fourteen frequently employed and quoted bridge pier scour predictions to published field and laboratory data collected from different sources, as well as the author's experimental results, to determine which predictors yielded a reasonable estimation of the bridge pier's local scour depth. The extent of efficiency of every predictor was determined by calculating the data percentage coverage within a difference ratio band of 0.5 to 2.0. He plotted scatter grams to visualize the data and ran statistical tests. The research is useful to hydraulic engineers who are interested in cost-effective design and bridge construction.

Padmini Khwairakpam, Soumendu Sinha Ray, Subhasish Das, Rajib Das and Asis Mazumdar (2012) executed a sequence of clear water scour tests in a tilting flume with a circular pier under various densimetric Froude number and inflow depth conditions. A single $50 \mathrm{~mm}$ diameter pier was employed in the tests, which was embedded in a sand bed with an average particle size of d50 $=0.365 \mathrm{~mm}$. The complete scour geometry (depth, length, width, area, and volume) has been found to be dependent on the densimetric Froude number (FD50) and inflow depth (h). Empirical formulae for scour depth, scour length, scour width, scour area, and scour volume have been proposed based on the collected findings.

The parameters of the scour hole computed using the suggested equations were compared to those derived from actual findings and found to be extremely similar, as shown in figure (2.2).

Mohd. Sarfaraz (2011) tested the feasibility of utilizing a mathematical model relying on river mechanics principles to evaluate the migratory characteristics of meandering rivers. To gain data for river management, existing models were employed to study the scouring of curved channels and the migrating of meandering channels. The models' applicability to the Madhumati River in Bangladesh has been given special consideration. Previous bed topography models were reviewed and their validity investigated in order to assess local scouring caused by curved flows. The transverse bed profile has been discovered to be reasonably easy to compute. The use of numerical simulations to predict channel shifting has been recognized as an essential tool for conducting site adaptive countermeasures in the management of rivers. Previous researchers' meander migration models were used to predict the migration of a Mathematic River meander bend, and the findings were compared to corresponding field data. Meander migration models provide a useful and simple tool for analyzing meandering channel migration characteristics. Yuan Zhai, M.S. (2010) investigated the timedependent scour depth under bridge-submerged flow. In his thesis, he specifically focused on the experimental study for time-dependent scour depth under bridge-submerged flow. The experiments 
were conducted in a self-contained re-circulating tilting flume where two uniform sediment sizes and one model bridge deck with three different inundation levels were tested for scour morphology. A semi-empirical model was implemented. The scour depth, at a bridge crossing, was determined based on the equilibrium scour depth of a design flood (e.g., 50-year, 100-year, and 500-year flood events). This is unnecessarily larger than a real maximum scour depth during a bridge life span since the peak flow period of a flood event is often much shorter than the corresponding scour equilibrium time. The proposed method can appropriately reduce the design depth of bridge scour according to design flow and a peak flow period, which could be translated into significant savings in the construction of bridge foundations. Mubeen Beg (2013) mentioned that the accurate estimation of maximum local scour depth at the bridge piers is vital for safe and economical design of bridges. The available predictors produce wide range of scour estimates for the same set of data. He testified fourteen commonly used and cited bridge pier scour predictors against published laboratory and field data obtained from various sources and author's experimental data in order to ascertain which of the predictors produce a reasonable estimate of the bridge pier local scour depth. The degree of performance of each predictor was accomplished by determining the percentage of data coverage between a band of discrepancy ratio of 0.5 to 2.0. He plotted scatter grams and carried out statistical tests. The study is useful for the hydraulic engineers concerned with economical design and construction of bridges.van Rijn, Leo C. (1993) investigated the principles of sediment transport in rivers, estuaries and coastal waters.Venkatadri, C. (1965) studied the scour around bridge piers and abutments. White W. R. (1973) examined the scour around bridge piers in steep streams.Sheppard, D. M. (2004) investigated the local sediment scour mechanism. Sheppard, D. Max, Mufeed Odeh and Tom Glasser (2004), Sheppard, D. Max, Mufeed Odeh and Tom Glasser (2002) and Sheppard, D. Max, Mufeed Odeh, Athanasios Pritsivelis, and Tom Glasser. (2000) executed large scale clear water local pier scour experiments.

Sheppard, D. Max. (2000) introduced a method for scaling local sediment scour depths from model to prototype. Breusers, H.N.C., Nicollet, G. and Shen, H.W. (1977) investigated the local scour around cylindrical piers. Melville, B.W., and Chiew, Y.M. (1999) studied the time scale for local scour at bridge piers. Ahmed Helmey (2017) investigated local scours around bridge piers. Local scours around bridge piers caused by unsteady flow were measured in their research. The experiments were 6 sex piers Shape in curved channel and relative

\section{Theoretical Approach:}

The analysis of the scours using different piers positions is developed theoretically by two methods, Dimensional analysis and Macroscopic approach. 


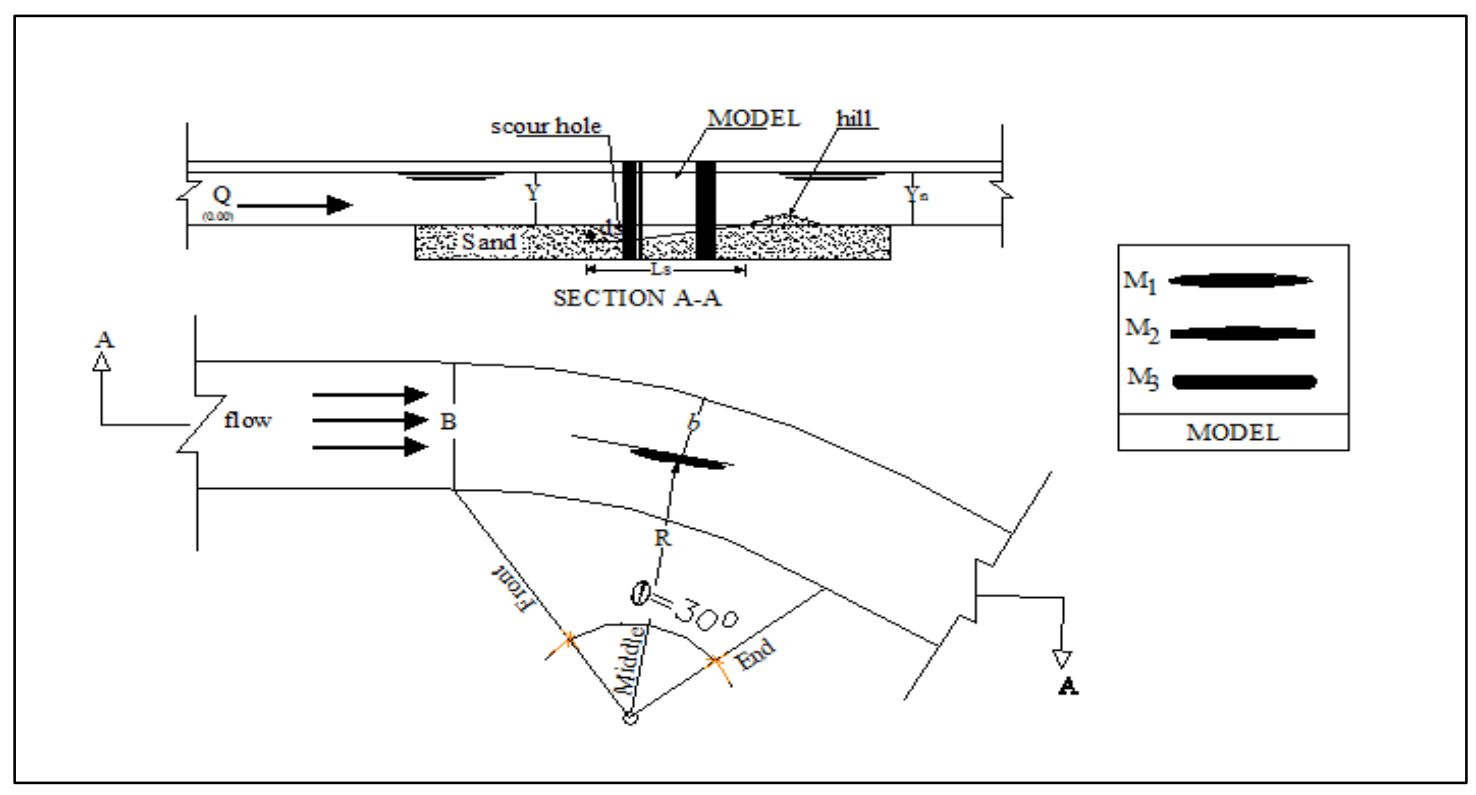

Figure.1 all parameters' definition sketches.

\subsection{Dimensional Analysis}

The dependent variables in this study are the scour hole's depth and length. As a function of all other independent variables, it can be stated as follows.

$$
\mathrm{ds}=\Phi\left(\mathrm{B}, \mathrm{b}, \mathrm{ds}_{\mathrm{m}}, \mathrm{t}, \mathrm{L}_{\mathrm{s}}, \mathrm{L}_{\mathrm{sm}}, \mathrm{Y}, \mathrm{Q}, \rho, \mathrm{g}, \mu, \boldsymbol{\varnothing}, \mathrm{D}_{50}, \mathbf{R}, \mathbf{S . G}, \boldsymbol{\theta}\right)
$$

These variables are identified in Fig. 1 and can be divided into five categories as follows:

\subsection{Characteristics of the Boundary}

$\mathrm{B}=$ Channel width. $\quad \mathrm{b}=$ the distance between the pier and the cannel side

$\mathrm{R}=$ the curvature radius $=$ Pier thickening

$\mathrm{g}=$ Gravitational acceleration

\subsection{Characteristics of flow}

$\mathrm{Q}=$ Discharge. $\quad \mathrm{Y}=$ the depth of the water

\subsection{Characteristics of fluid}

$\mathrm{P}=$ Mass density of fluid. $\mathrm{V}=$ Kinematic viscosity.

$\mathrm{g}=$ Gravitational acceleration 


\subsection{Scour hole parameters}

ds = scour depth. $\quad$ LS= Length of scour hole.

$\theta=$ Angle of curved channel dsm= Maximum scour depth

$\mathrm{L}_{\mathrm{sm}}=$ mix scour Length

\subsection{Soil characteristics}

$\mathrm{S} . \mathrm{G}=$ Soil Specific gravity. D50 = mean diameter of sediments.

where, $\mathrm{B}$ is the channel width, $\mathrm{Q}$ is the discharge, $\rho$ is the fluid density, $\mathrm{g}$ is the gravitational acceleration, $\mu$ is the dynamic viscosity, S.G is the specific density and $\varnothing$ is the specified soil diameter and R is the radius of curvature. Soil tested wasn't changed, so the parameters $\varnothing$ and S.G could be deleted from the variables.

There ten variables give pi-terms and two repeating variables using the Buckingham pi-theorem, these variables can be easily arranged the following non-dimensional pi-terms.

$$
\begin{aligned}
& \Pi_{1}=\mathrm{d}_{\mathrm{s}} / \mathrm{B} \quad \Pi_{2}=\mathrm{b} / \mathrm{B} \quad \Pi_{3}=\mathrm{d}_{\mathrm{sm}} / \mathrm{B} \quad \Pi_{4}=\mathrm{L}_{\mathrm{sm}} / \mathrm{B} \quad \Pi_{5}=\mathrm{L}_{\mathrm{S}} / \mathrm{B} \quad \Pi_{6}=\mathrm{B} / \mathrm{Y} \quad \Pi_{7}=\mathrm{QT} / \mathrm{B}^{3} \quad \Pi_{8}=\mathrm{D}_{50} / \mathrm{B} \\
& \Pi_{9}=\mathrm{Q}_{2} / \mathrm{B}^{5} \mathrm{~g}
\end{aligned}
$$

The following relationship can be derived using the properties of pi-terms:

$$
\phi=\left(\frac{d s}{d s m}, \frac{L s}{L s m}, \frac{b}{B}, \frac{D_{50}}{R}, \frac{V}{\sqrt{g y}}, \theta\right)
$$

Where:

$\mathrm{d}_{\mathrm{s}} / \mathrm{d}_{\mathrm{sm}}$ is the relative scour depth

$\mathrm{L}_{\mathrm{s}} / \mathrm{y}$ is the relative length of scour hole to be protected

$\mathrm{b} / \mathrm{B}$ is e, the contraction ratio

$\mathrm{QT} / \mathrm{y}^{2}$ is the time factor

$\mathrm{V} / \sqrt{\mathrm{gy}}$ is Fr the Froude number through the channel

We reach the following functions:

$$
\begin{aligned}
& \frac{d_{s}}{d_{s m}}=\phi\left(\frac{L_{s}}{L_{s m}}, \frac{b}{B}, \frac{D_{50}}{B}, F r\right) \\
& \frac{L_{s}}{L_{s m}}=\phi\left(\frac{d_{s}}{d_{s m}}, \frac{b}{B}, \frac{D_{50}}{B}, F r\right)
\end{aligned}
$$

\section{Experimental work}

Thirty (30) tests were conducted. The experimental investigation was carried out in the hydraulic laboratory of Al-Azhar University's Faculty of Engineering in Cairo. The flume is $800 \mathrm{~cm}$ long and has a 60x30 $\mathrm{cm} 2$ rectangular cross section steel frame with translucent polycarbonate sides that enable visual inspection of the surface of water. The flume layout is shown in detail in Figure 1,2 and 3.

The physical model (pier) is made from Polly carbonate. Two models shaped is suggested (Elliptical and Oblong) shape. The test program was done on two different shapes, Elliptical, Oblong, as indicated in table (1). Experiments have been performed in clear water with varying water discharges of 17.15, 23.93, 29.34, 31.86, 
and $37.831 / \mathrm{sec}$ to determine the maximum depth of scour. Table 1 summarizes the test conditions for every type of bridge pier.

Table (1) test conditions for a series of tests.

\begin{tabular}{|c|c|c|c|c|c|}
\hline $\mathrm{NO}$ & shapes & $\mathrm{Y}(\mathrm{cm})$ & $\begin{array}{l}\text { Velocity in channel } \\
\mathrm{cm} / \mathrm{s}\end{array}$ & $\mathrm{Q}(\mathrm{L} / \mathrm{s})$ & $\mathrm{Fr}$ \\
\hline \multirow{5}{*}{$\mathrm{M}_{1}$} & \multirow{5}{*}{ Elliptical } & \multirow{5}{*}{12.30} & 17.15 & 13.89 & 0.16 \\
\hline & & & 23.97 & 19.41 & 0.21 \\
\hline & & & 29.34 & 23.77 & 0.26 \\
\hline & & & 34.62 & 28.04 & 0.29 \\
\hline & & & 37.83 & 30.64 & 0.34 \\
\hline \multirow{5}{*}{$\mathrm{M}_{2}$} & \multirow{5}{*}{ Hexagonal } & \multirow{5}{*}{12.30} & 17.15 & 13.89 & 0.16 \\
\hline & & & 23.97 & 19.41 & 0.21 \\
\hline & & & 29.34 & 23.77 & 0.26 \\
\hline & & & 34.62 & 28.04 & 0.29 \\
\hline & & & 37.83 & 30.64 & 0.34 \\
\hline \multirow{5}{*}{$\mathrm{M}_{3}$} & \multirow{5}{*}{ Oblong } & \multirow{5}{*}{12.30} & 17.15 & 13.89 & 0.16 \\
\hline & & & 23.97 & 19.41 & 0.21 \\
\hline & & & 29.34 & 23.77 & 0.26 \\
\hline & & & 34.62 & 28.04 & 0.29 \\
\hline & & & 37.83 & 30.64 & 0.34 \\
\hline
\end{tabular}

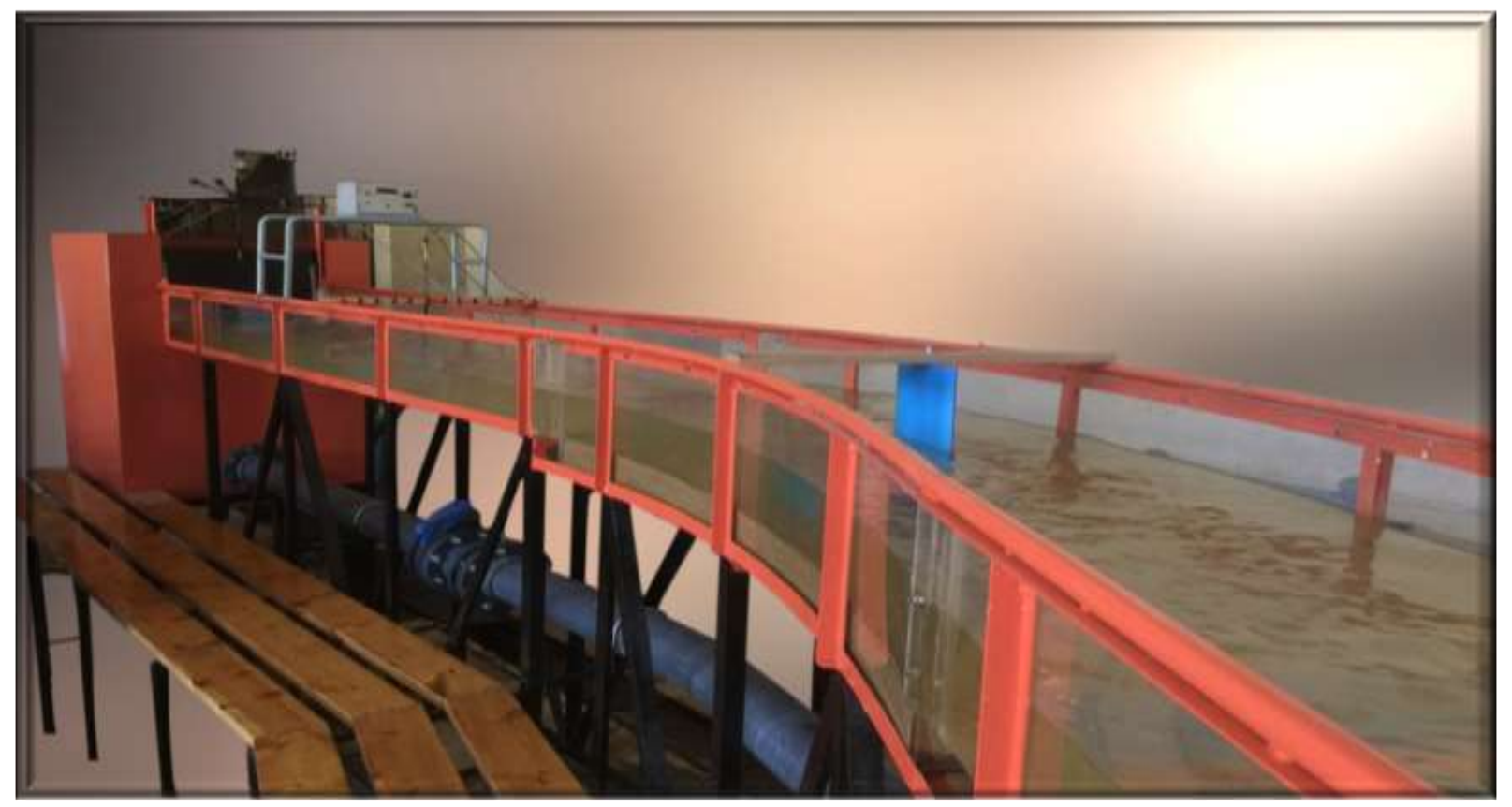

Figure 1. General view of the experimental flume at Al- Azhar University. 


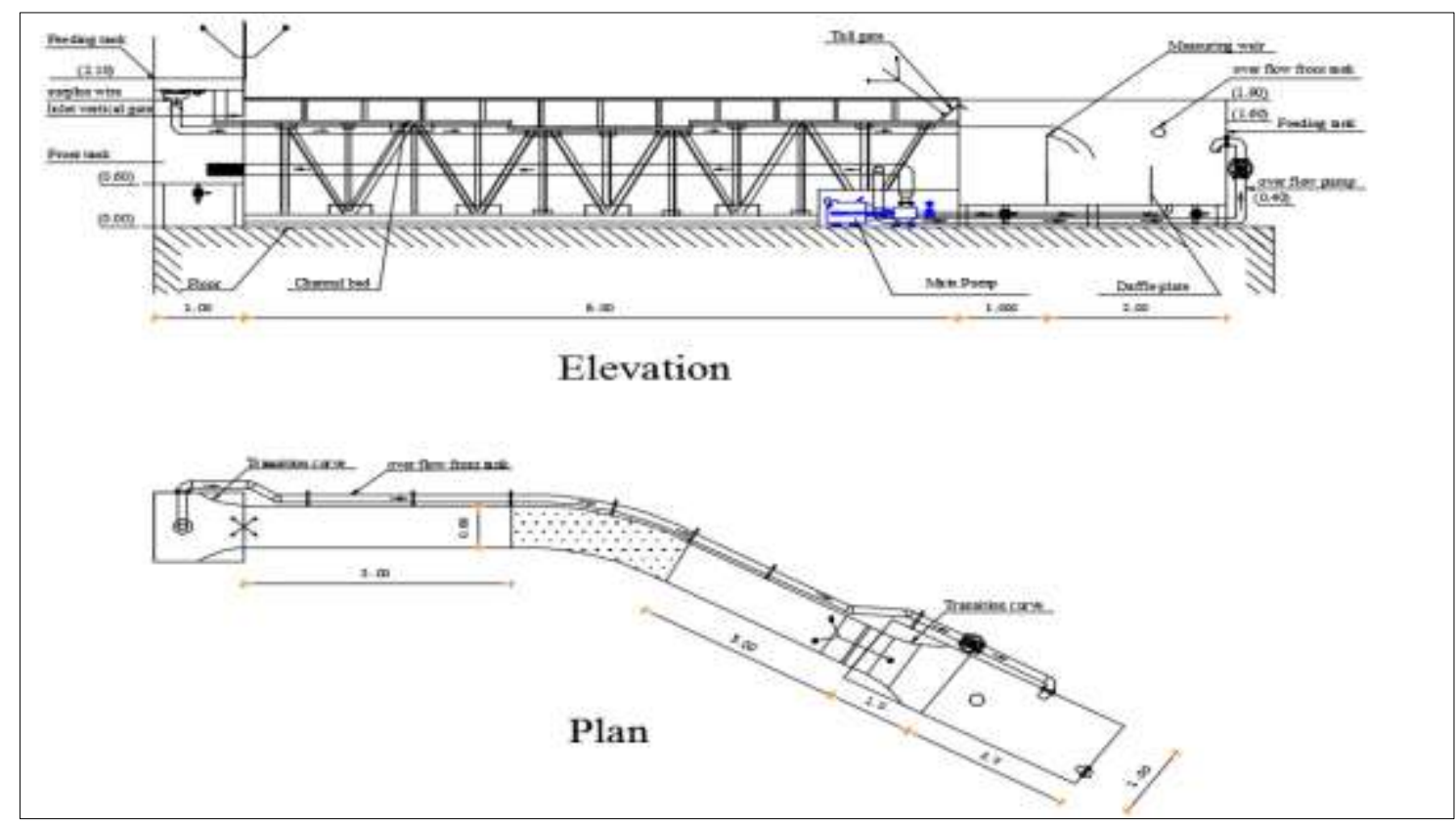

Figure 2. The experimental flume layout

The model is placed at the positions relative to the inlet gate with a relative floor length $(\mathrm{b} / \mathrm{B})$ equal to 0.5 . The bed material (sand) has been levelled precisely, and the levelling precision has been verified using a water gauge and an ultrasonic meter, as shown in photo (2). The model is fitted in a certain position. Ultrasonic devices have been employed to measure the water levels and depths as well as the scour length and depth. During the run. 


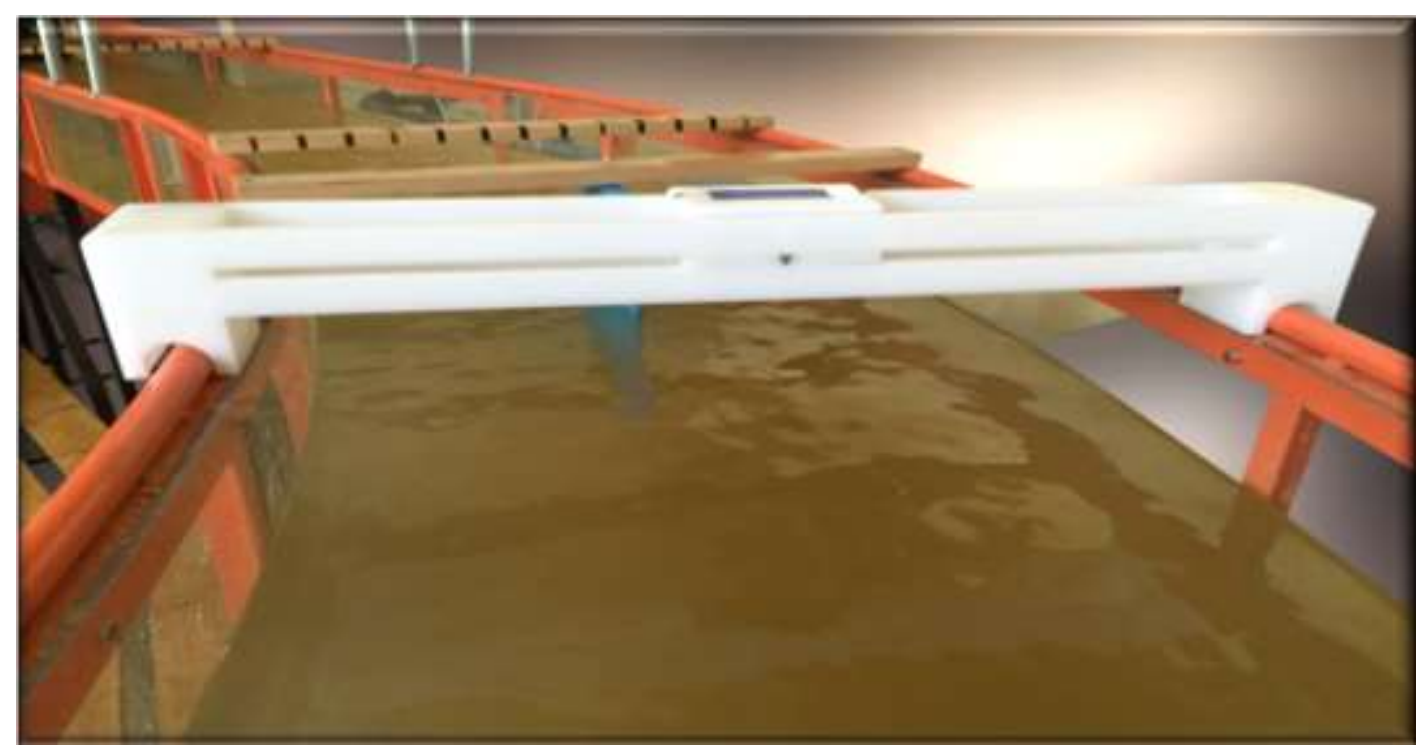

Figure 3. View of measuring devices (Ultrasonic devices - one spot).

\section{Experimental work}

Forty fife (45) experiments were executed to three (3) different angels $(\Theta)\left(0.0^{\circ}-15^{\circ}-30^{\circ}\right)$. Five distinct discharges have been used. Measurements have been carried out. Photos are taken after observations have been made.

Such measurements, observations, and photos have been recorded and stored. They have been analyzed, comprehended, and graphed. These graphs are shown here. From the standpoint of scour depth and scour depth, they are as follows:

\subsection{Representing The Results of the Scour Depth}

Figures $(4,5)$ and (6) were plotted to present the relation between $F_{r}$ and $d_{s} / d_{s m}$ from the figures, the following were observed:

- In general, $\mathrm{d}_{\mathrm{s}}$ is directly proportional to $\mathrm{F}_{\mathrm{r}}$.

In the First Position $(\Theta)=0.0^{\circ}$ : -

- For all the tested cases the appropriate pier Elliptical shape $\left(\mathrm{M}_{1}\right)$ it contributed in the ratio of the scour depth ranged $39 \%-70 \%$.

- For all the tested cases the appropriate pier Hexagonal shape $\left(\mathrm{M}_{2}\right)$ it contributed in the ratio of the scour depth ranged $45 \%-88 \%$.

- For all the tested cases the appropriate pier Oblong shape $\left(\mathrm{M}_{3}\right)$ it contributed in the ratio of the scour depth ranged $48 \%-100 \%$.

In the middle Position $(\Theta)=15^{\circ}$ : -

- For all the tested cases the appropriate pier Elliptical shape $\left(\mathrm{M}_{1}\right)$ it contributed in the ratio of the scour depth ranged $33 \%-83 \%$. 
- For all the tested cases the appropriate pier Hexagonal shape $\left(\mathrm{M}_{2}\right)$ it contributed in the ratio of the scour depth ranged $24 \%-67 \%$.

- For all the tested cases the appropriate pier Oblong shape $\left(\mathrm{M}_{3}\right)$ it contributed in the ratio of the scour depth ranged $36 \%-100 \%$.

In the end Position $(\Theta)=30 \mathrm{o}$ : -

- For all the tested cases the appropriate pier Elliptical shape $\left(\mathrm{M}_{1}\right)$ it contributed in the ratio of the scour depth ranged $33 \%-70 \%$.

- For all the tested cases the appropriate pier Hexagonal shape $\left(\mathrm{M}_{2}\right)$ it contributed in the ratio of the scour depth ranged $30 \%-88 \%$.

- For all the tested cases the appropriate pier Oblong shape $\left(\mathrm{M}_{3}\right)$ it contributed in the ratio of the scour depth ranged 39\% - 100\%.

From the above, obvious was that the appropriate position for the pier, among all the tested position, is at end $(\Theta)=30 \mathrm{o}$ for Elliptical shape $\left(\mathrm{M}_{1}\right)$, middle Position $(\Theta)=15^{\circ}$ Hexagonal shape $\left(\mathrm{M}_{2}\right)$ and middle Position $(\Theta)=$ $15^{\circ}$ Oblong shape $\left(\mathrm{M}_{3}\right)$.

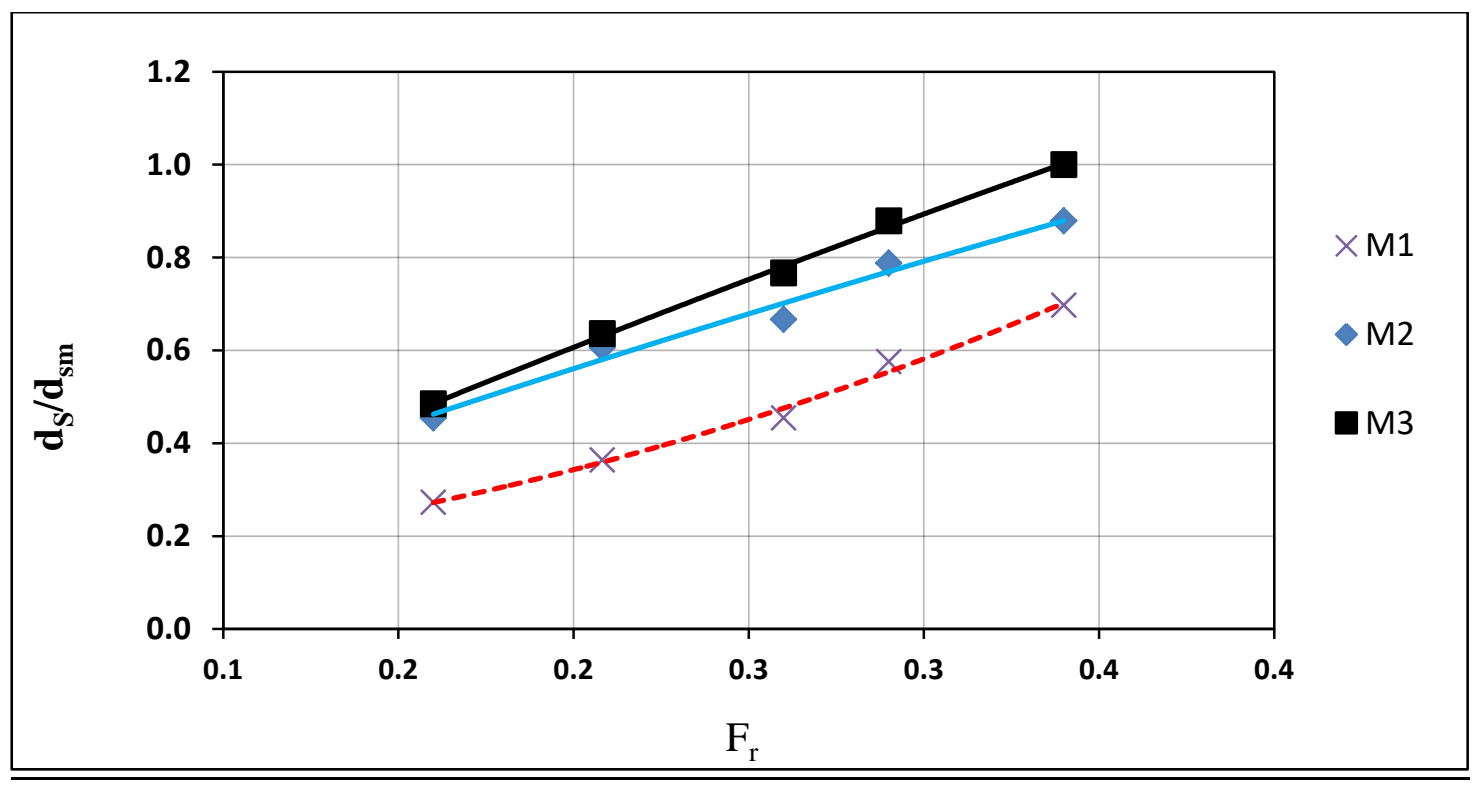

Figure 4. The Relation between $(\mathrm{Fr})$ and $(\mathrm{ds} / \mathrm{dsm})$ for $(\theta)=0.00$ 


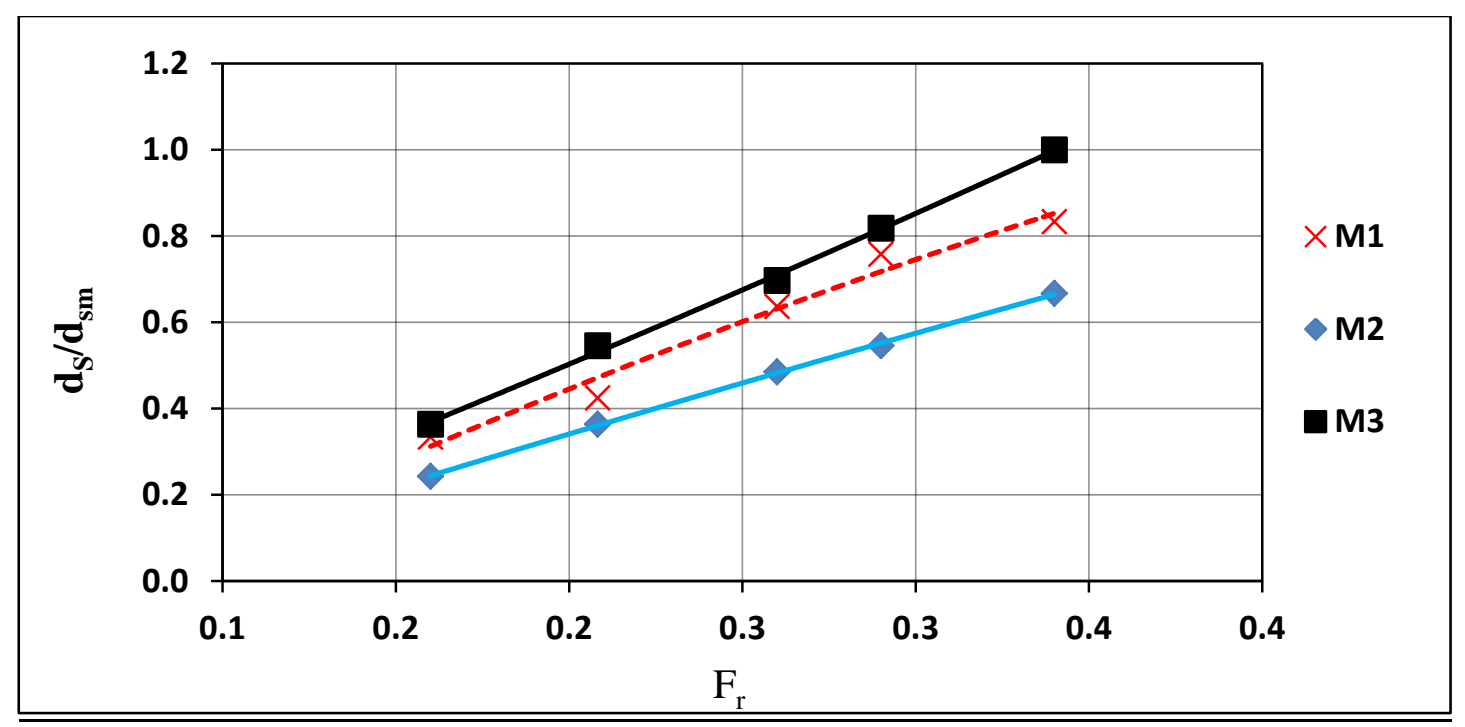

Figure 5. The Relation between $(\mathrm{Fr})$ and $(\mathrm{ds} / \mathrm{dsm})$ for $(\Theta)=150$

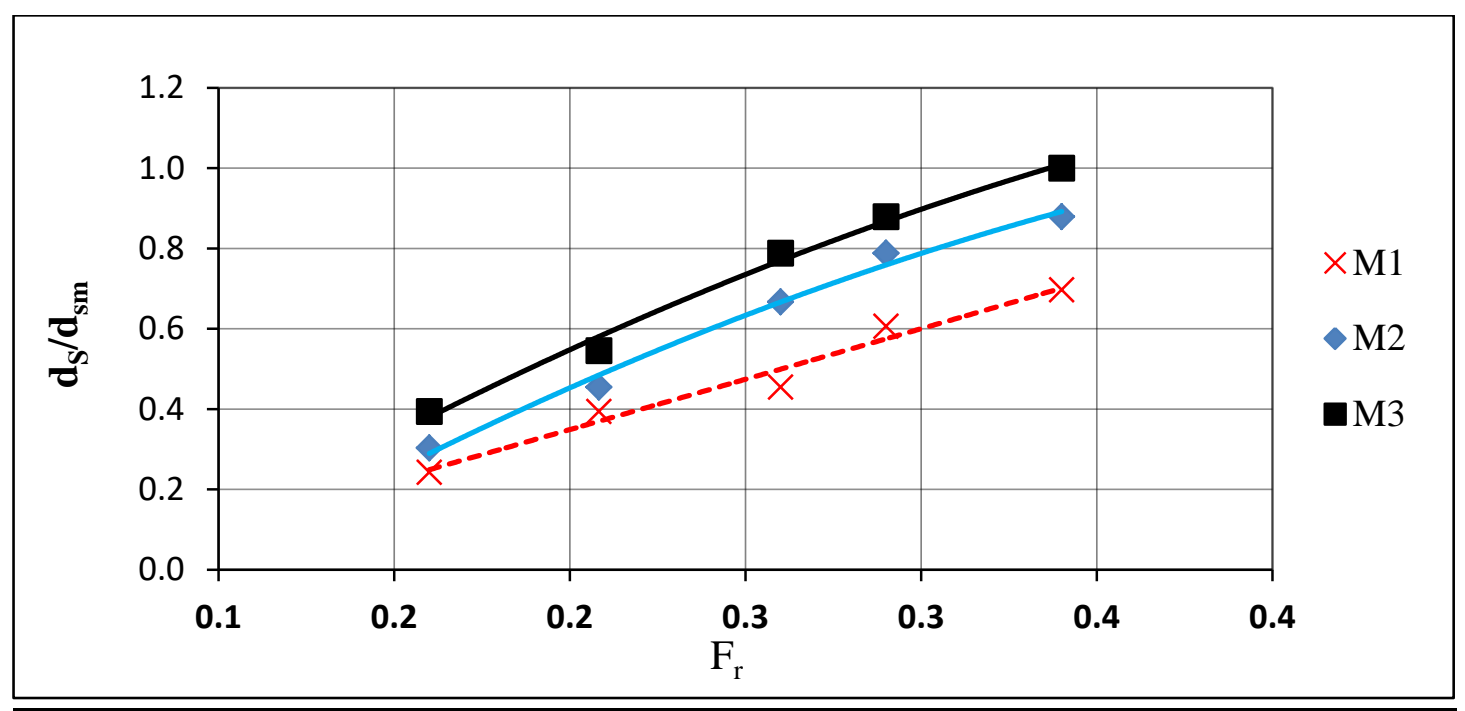

Figure 6. The Relation between $(\mathrm{Fr})$ and $(\mathrm{ds} / \mathrm{dsm})$ for $(\Theta)=30^{\circ}$

\subsection{Representing the Results of the Scour Length}

Figures $(7,8)$ and (9) were plotted to present the relation between $F_{r}$ and $L_{s} / L_{s m}$ from the figures, the following were observed:

- In general, $\mathrm{L}_{\mathrm{s}} / \mathrm{L}_{\mathrm{sm}}$ is directly proportional to $\mathrm{F}_{\mathrm{r}}$.

In the First Position $(\Theta)=0.0^{\circ}$ : - 
- For all the tested cases the appropriate pier Elliptical shape $\left(\mathrm{M}_{1}\right)$ it contributed in the ratio of the scour length ranged $20 \%-75 \%$.

- For all the tested cases the appropriate pier Hexagonal shape $\left(\mathrm{M}_{2}\right)$ it contributed in the ratio of the scour length ranged $35 \%-100 \%$.

- For all the tested cases the appropriate pier Oblong shape $\left(\mathrm{M}_{3}\right)$ it contributed in the ratio of the scour length ranged $25 \%-90 \%$.

In the middle Position $(\Theta)=15^{\circ}$ : -

- For all the tested cases the appropriate pier Elliptical shape $\left(\mathrm{M}_{1}\right)$ it contributed in the ratio of the scour length ranged $25 \%-100 \%$.

- For all the tested cases the appropriate pier Hexagonal shape $\left(\mathrm{M}_{2}\right)$ it contributed in the ratio of the scour length ranged $20 \%-85 \%$.

- For all the tested cases the appropriate pier Oblong shape $\left(\mathrm{M}_{3}\right)$ it contributed in the ratio of the scour length ranged $23 \%-90 \%$.

In the end Position $(\Theta)=30^{\circ}$ : -

- For all the tested cases the appropriate pier Elliptical shape $\left(\mathrm{M}_{1}\right)$ it contributed in the reduction of the scour length ranged $18 \%-75 \%$.

- For all the tested cases the appropriate pier Hexagonal shape $\left(\mathrm{M}_{2}\right)$ it contributed in the reduction of the scour length ranged $25 \%-100 \%$.

- For all the tested cases the appropriate pier Oblong shape $\left(\mathrm{M}_{3}\right)$ it contributed in the reduction of the scour length ranged $25 \%-90 \%$.

From the above, obvious was that the appropriate position for the pier, among all the tested position, is at the end $(\Theta)=30^{\circ}$ for Elliptical shape $\left(M_{1}\right)$, middle Position $(\Theta)=15^{\circ}$ Hexagonal shape $\left(M_{2}\right)$ and middle Position $(\Theta)=15^{\circ}$ Oblong shape $\left(\mathrm{M}_{3}\right)$.

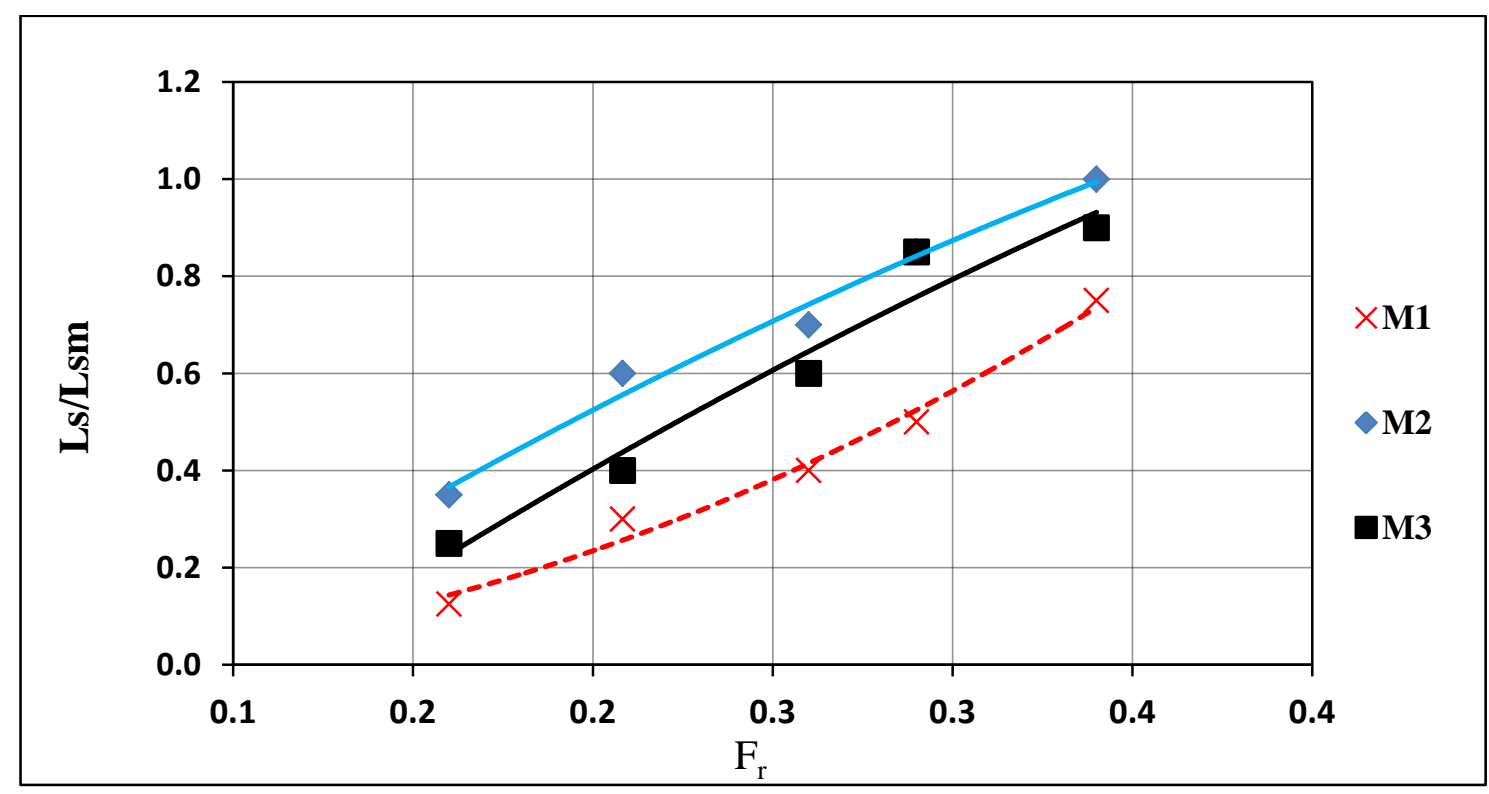

Figure 7. The Relation between $(\mathrm{Fr})$ and $\left(\mathrm{Ls} / \mathrm{d}_{\mathrm{sm}}\right)$ for $(\boldsymbol{\theta})=0.0^{\circ}$ 


\section{Conclusions and Recommendations}

Based on the above investigation phases, the concluded aspects were listed and are represented on table (2). In general, the conclusions are as follows:

- In general, we can put the piers in curved channels with taking some precautions

- The lowest percentage of scour depth occurred in the middle of curved $\left(\Theta=15^{\circ}\right)$ of the Hexagonal shape $\left(\mathrm{M}_{2}\right)$.

- The highest percentage of scour depth occurred in the first of curved $\left(\Theta=0.0^{\circ}\right)$ of the oblong shape $\left(\mathrm{M}_{3}\right)$.

- The lowest percentage of scour length occurred in the end of curved $\left(\Theta=30^{\circ}\right)$ of the Elliptical shape $\left(\mathrm{M}_{1}\right)$.

-

- The highest percentage of scour length occurred in the first of curved $\left(\Theta=0.0^{\circ}\right)$ of the Hexagonal shape $\left(\mathrm{M}_{2}\right)$.

Based on the above, the following recommendations were foreseen and are given, as follows:

- Other innovative pier forms are to be investigated and tested.

- A curved range of angle are to be investigated and tested.

- A wider range of angles, Froude number and discharge are to be tested

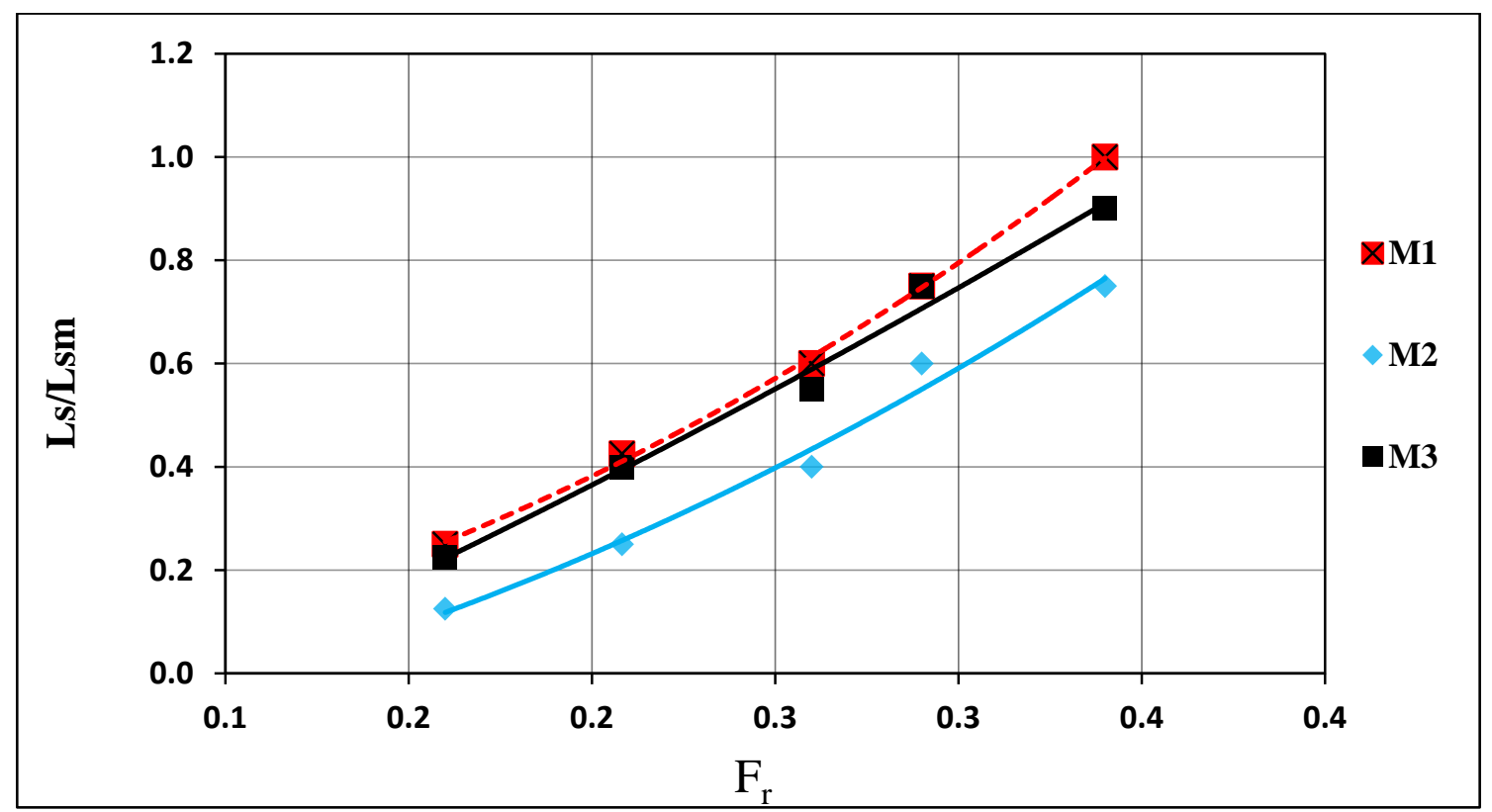

Figure 8. The relation between $(\mathrm{Fr})$ and $\left(\mathrm{Ls} / \mathrm{L}_{\mathrm{sm}}\right)$ for $(\Theta)=15^{\circ}$ 


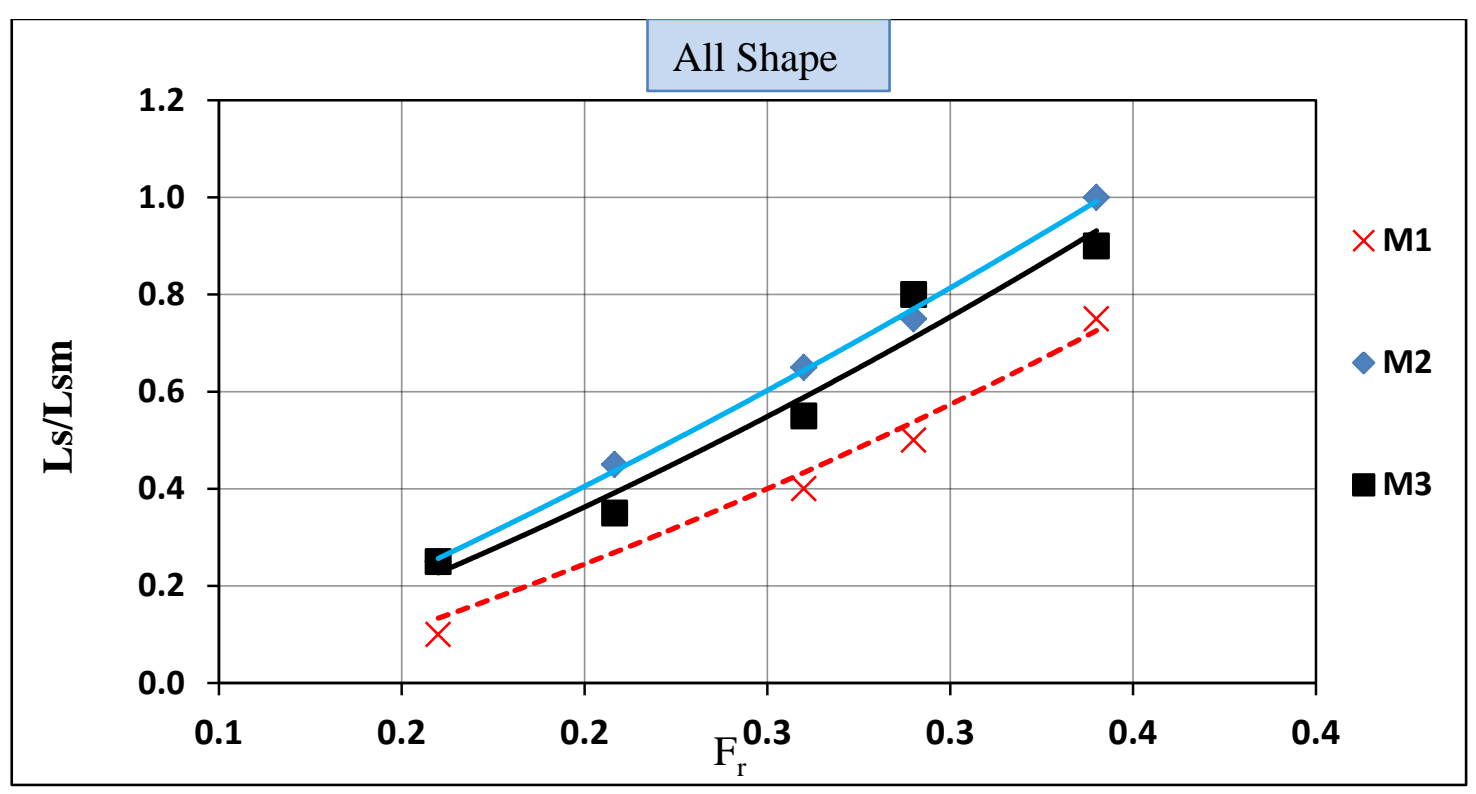

Figure 9. The Relation between $(\mathrm{Fr})$ and $(\mathrm{Ls} / \mathrm{Lsm})$ for $(\boldsymbol{\theta})=30^{\circ}$

Table (2) A summary to the effect of the pier form

\begin{tabular}{|c|c|c|c|}
\hline $\begin{array}{l}\text { Position of } \\
\text { Pier }\end{array}$ & shape & $\begin{array}{c}\text { Scour depth } \\
\mathrm{d}_{\mathrm{s}} / \mathrm{d}_{\mathrm{sm}} \%\end{array}$ & $\begin{array}{l}\text { Scour length } \\
\mathrm{L}_{\mathrm{s}} / \mathrm{L}_{\mathrm{sm}} \%\end{array}$ \\
\hline \multirow{3}{*}{$0.0^{\circ}$} & $M_{1}$ & $39-70$ & $20-75$ \\
\hline & $\mathbf{M}_{2}$ & $45-88$ & $35-100$ \\
\hline & $\mathbf{M}_{3}$ & $48-100$ & $25-90$ \\
\hline \multirow{3}{*}{$15^{\circ}$} & $\mathbf{M}_{1}$ & 33 - 83 & $25-100$ \\
\hline & $M_{2}$ & $24-67$ & $20-85$ \\
\hline & $\mathbf{M}_{3}$ & $36-100$ & $23-90$ \\
\hline \multirow{3}{*}{$30^{\circ}$} & $M_{1}$ & $33-70$ & $18-75$ \\
\hline & $M_{2}$ & 30 - 88 & $25-100$ \\
\hline & $M_{3}$ & $39-100$ & $25-90$ \\
\hline
\end{tabular}

\section{REFERENCES}

[1] A. Azhari, S.F., B.A. Saghravani, and M Nezhad, Scour around a Bridge Pier, The Florida State University, Electronic Theses, Treatises and Dissertations The Graduate School, 10-28-2005, XVIII International Conference on Water Resources, CMWR 2010.

[2] A. Helmey. (2017). "Studying local scour around bridge piers in curved channels", thesis, AlAzhar University faculty of Engineering, Cairo, Egypt.

[3] A. Khodabakhshi, MojtabaSaneie, AbdolnabiAbdohKolahchi (2014). Study on Effect of Slot Level on Local Scour around Bridge Pier, IJRET: International Journal of Research in Engineering and Technology, Volume: 03, Feb-2014. 
[3] A._Hassan al Shukur (2016). Experimental study of bridge pier shape to local scour vol.7 Issue Feb 2016 .

[4] C. J., Baker, (1981). New design equation for scour around bridge piers, Journal of Hydraulic Division, A.S.C.E., Vol. 107 HY-4.

[5] Ch. Lien. Yen, Jihn-Sung Lai and Wen-Yi Chang (2001), Modeling of 3D Flow and Scouring around Circular Piers, Proc. Natl. Sci. Counc. ROC(A), Vol. 25, No. 1, 2001. pp. 17-26

[6] F. Ahmed, and N Rajaratnam. "Flow around bridge piers, J Hyd. Eng. ASCE, 1998; 124(3): 288-300.

[7] H .N. C.,Breusers. Nicollet, G. and Shen, H.W. (1977). Local scour around cylindrical piers, Journal of Hydraulic Research, Vol. 15 No, 211-252.

[8] H. Azamathulla,., Ghani, A., Zakaria, N., and Guven, A. (2010) "Predict Bridge Pier Scour" Journal of Hydraulics (2010).

[9] H. N .C., Breusers. \&Raudkivi, A.J. (1991). Scouring, Hydraulic Structure, Manual, I.A.H.R., Balkema, Rotterdam, Netherlands.

[10] H. N. C., Breusers, (1972). Local scour near offshore structures, Delft Hydraulics Laboratory, Publication No. 105.

[11] J. Chabert\& P. Engeldinger (1956). Etude des Affouillementautour des Piles des ponts (Study on scour around bridge Piers), Laboratoire National d'Hydraulique, Chatou, France.

[12] K. Arunachalam, (1965). Scour around bridge piers, Journal of Indian Roads Congr. 29 No.2, 189-207

[13] M. Beg (2013). "Predictive competence of Existing Bridge Pier Scour Depth Predictors", European International Journal of Science and Technology Vol. 2 No. 1 February 2013.

[14] M. Sarfaraz (2011). Migration Characteristics Of Meandering Channels Based On River Morphodynamics, European Science Foundation Conference, November 28 to December 1, 2011, SantFeliu de Guixols, Spain.

[15] Y. Emami, S. Amin Salamatian And Masoud Ghodsian (2008). Scour at Cylindrical Bridge Pier in A 180 Degree Channel Bend, Fourth International Conference on Scour and Erosion 2008.

[16] Y. M. Chiew \& B. M. Melville, (1987). Local scour around piers, Journal of Hydraulic Research, Vol. 25 No. 1, 15-26. 